\title{
The Role of Environmental Taxes as a Fiscal Instrument for Mitigation of Environmental Pollution: Lithuanian Case
}

\author{
Astrida Miceikiene, \\ Jurate Lideikyte, \\ Vytautas Magnus University, \\ Faculty of Bioeconomy Development, Lithuania \\ Jurate Savickiene, \\ Jevgenija Cesnauske, \\ Kauno Kolegija, University of Applied Sciences, \\ Faculty of Business, Lithuania
}

Doi:10.19044/esj.2019.v15n25p26 URL:http://dx.doi.org/10.19044/esj.2019.v15n25p26

\begin{abstract}
Environmental taxes are an important fiscal instrument for a country, as they help in the efforts towards the environmental policy goals. Taxes based on the polluter-pays principle influence the behaviour of market participants by discouraging them from undertaking an environmentally detrimental activity and by attracting additional budget funds for mitigation of the consequences of this kind of activity. Environmental protection is one of the priority areas in the Republic of Lithuania, meaning that it is highly important to assess the effect of the environmental taxes on the environmental pollution in the country and improve them following the best practice of other countries. The methodology of empirical research is based on the methods of descriptive statistics. According to the official statistics of Lithuania, majority of the environmental taxes collected and the maximum volumes of the emissions into the atmosphere are generated by the following groups of economic activities: agriculture, forestry and fishing; manufacturing; wholesale and retail trade, repair of motor vehicles and motorcycles. The study of trends in the environmental tax dynamics in Lithuania and other countries has demonstrated that Lithuania is the country which moves towards an environmental tax reform. Nonetheless, it is important to reconsider the country's environmental tax rates and tax benefits and provide for the incentives for the groups of economic activities which are characterised by the highest GDP potential and lower environmental pollution.
\end{abstract}


Keywords: Environmental taxes, Environmental pollution, Polluter-pays, Environmental tax reform

\section{Introduction}

Social and economic development of countries in the present world is being increasingly based on humanist values, namely, reconciliation of the public and private sector interests in addressing the issues of sustainable development. These issues are closely related to the ecological balance and are considered to be one of the key areas of focus in the majority of developed and developing countries. In this context, state regulation becomes particularly relevant, as it is intended to provide environmental guidance for the human activity. In view of the above, the measures helping achieve the environmental goals at the lowest economic costs become highly important. Environmental taxes could be referred to as one of the key measures of this kind.

Environmental taxes are a flexible and economically efficient fiscal policy measure intended for mitigation of environmental pollution, based on the polluter-pays principle, and aimed at eliminating the limitations in terms of continuous economic growth as well as ensuring sustainable development in the long run. Environmental taxes are capable of discouraging the market participants from an environmentally detrimental behaviour and of preserving the environment by "getting the prices right". Application of the taxes is economically based on their economic effect on the market, in contrast to the normative or administrative methods (Environmental taxes, 2013).

Environmental protection is one of the priority areas in Lithuania. The Lithuanian National Strategy for Sustainable Development sets down the vision, where "Lithuania is a full-fledged member of the EU, having preserved its distinct culture and successfully adjusted to the challenges of globalization, and consistently pursuing the policy of sustainable development, which ensures a healthy environment, adequate use of natural and intellectual resources, a moderate yet stable economic growth, as well as public welfare and reliable social guarantees" (The Strategy for Sustainable Development, 2003). In view towards the vision, particular focus in the country is placed on the environmental issues and solutions in line with the sustainable development principles.

The aim of this research is to assess the effect of environmental taxes on the environmental pollution in Lithuania and generate the recommendations on improvement of environmental taxes.

The above-mentioned aim was accomplished by fulfilling the following research objectives:

- $\quad$ To provide theoretical justification of the importance of environmental taxes as a fiscal instrument for mitigation of environmental pollution; 
- $\quad$ To identify and assess the interplay between environmental taxes and environmental pollution in individual business sectors in Lithuania;

- To generate the recommendations on improvement of the environmental taxes in Lithuania.

Research methodology. To provide the justification of the importance of environmental taxes in terms of mitigation of environmental pollution, the analysis and synthesis of scientific literature and official legislative documents were employed. Analysis of the taxes, assessment of their links to environmental pollution and trends in the dynamics of the links were performed using the statistical data provided by the Lithuanian Department of Statistics and Eurostat. Research period: 2008-2016. The recommendations on improvement of environmental taxes in Lithuania were generated following assessment of the trends in environmental taxes and environmental tax reform in the selected countries, using the statistical data analysis and graphic imaging.

\section{Environmental Taxes: The Role in Mitigation of Environmental Pollution}

Environmental protection has been recognized as the issue of global importance in the end of the last century, following the adoption of the Kyoto Protocol - the first in history written commitment of the countries across the globe to take care of the climate changes. It provides for the commitments undertaken by the industrial countries in order to reduce the Greenhouse Gas (GHG) emissions which contribute to the global warming (Kyoto protocol, 1998).

Nonetheless, the developed countries had already applied environmental taxes, green movements, parties, initiatives, conferences for assessment of the environmental changes before the adoption of the Kyoto Protocol. In Europe, the enterprises generating carbon dioxide emissions which accounted for the highest environmental pollution and impact on the climate were subjected to the taxation in the first place. Subsequently, excise duties and additional taxes were imposed on fuel, in some countries - even on the vehicles (Miceikienè \& Čiulevičienè, 2014).

Eurostat, the Organisation of Economic Co-operation and Development (OECD) and the International Energy Agency (IEA) use the following definition of an environmental tax: "A tax whose tax base is a physical unit (or a proxy of a physical unit) of something that has a proven, specific negative impact on the environment, and which is identified in European System of Accounts as a tax" (Environmental taxes, 2013).

Pursuant to the Lithuanian National Strategy for Environmental Protection, environmental taxes are a fiscal measure intended to influence the environmental behaviour of the market participants by promotion of shifting 
from the consumer to green ${ }^{1}$ economy. The taxes comprise a significant part of an efficient tax system, favourable for both the environmental protection and economic growth. Environmental tax funds should be used as a fiscal measure encouraging economic entities to effectively comply with the established environmental requirements, find optimum environmental measures and implement low-waste and low CO2 technologies (The National Strategy for Environmental Protection, 2016).

The theoretical foundation of the environmental taxes as a fiscal instrument was laid down by the works by F. Ramsey and A. Pigou. In 1927, F. Ramsey published an article claiming that, in order to reduce the distortion caused by taxes, it is important to impose taxes on all activities and proposed the method of determination of the tax rates. Pursuant to the Ramsey rule, the optimum tax rate is determined to be in inverse proportion to the demand price elasticity of the tax base, i.e. the less elastic the damand, the higher the tax rate. This reduces the so-called "dead-weight costs" effect, i.e. distortion of an economic activity through taxation (Environmental Taxes, 2013). A. Pigu proposed using the dedicated corrective prices applicable to the market activity which causes a negative external effect. In view of this statement, environmental pollution is a typical example of negative consequences, which should be subjected to taxation in proportion to the degree of damage caused. Pursuant to the theory, environmental taxes, as corrective taxes, are intended to assimilate the marginal private costs to the marginal social costs, and the marginal private benefit to the marginal social it (Pigou, 1932).

In the $21^{\text {st }}$ century, the issues related to environmental taxes have been considered to be one of the key areas of focus, as the increasing environmental pollution caused by the $\mathrm{CO} 2$ emissions by both mobile and stationary sources affects the climate, quality of life, and various ecosystems. Consequently, environmental taxes are a relevant topic in various scientific literature which deals with their possibilities and specifics.

According to J. Albrecht (2006), environmental taxes may help create market for environmentally friendly products and new technologies. According to A. Bruvoll (2009), the goal of environmental taxes is market adjustment. P. Ekins et al. (2012) have emphasized that environmental taxes are significant in that they enable the persons liable for environmental pollution to consider the options which are more benefitial to them: paying taxes or changing the behaviour and paying a lower tax or avoiding any tax burden. Nonetheless, the determined tax rate should ensure that continuing an environmentally detrimental activity is too expensive for the polluter.

\footnotetext{
${ }^{1}$ Low-carbon technology-based, environmentally friendly, resource-efficient economy which does not have negative impact in terms of the climate change
} 
The polluter-pays principle is particularly important for formation of environmental taxes. This principle means that the entire liability, including the pecuniary liability, for the pollution or environmental damage caused by the use of natural resources is imposed on the polluters or consumers, i.e. all social and economic damages caused by pollution and use of resources are to be covered by the polluters themselves. The principle is aimed at making sure that the costs and liability for restoration of the depleted and polluted environment are imposed on the ones who benefit from this kind of activity or are the consumers of the natural resources, i.e. the costs of pollution mitigation measures would be covered by the respective polluter. This does not include the cases where identification of the polluter is impossible, or where the polluter cannot be held liable for the pollution or cannot be made to bear the restoration costs (Meškys, 2006).

The taxes which mitigate environmental pollution and are beneficial to the natural resources are important for the following reasons:

- they may lead to reduction of the economic costs in the efforts to achieve the aspired environmental condition and may serve as the encouragement to reduce the pollution;

- $\quad$ they may promote implementation of innovative technologies, as the polluters are interested in finding new ways of reducing the emissions;

- they can turn into the source of revenues for investments into environmental pollution and implementation of the environmental policy;

- $\quad$ they may help implement the principles of sustainable development (Miceikienė \& Čiulevičienè, 2014).

In the research studies, the effect of environmental taxes is usually defined from a positive perspective, and the environmental taxes are claimed to be capable of correcting the distortions in the tax system and mitigating or even eliminating the negative impact of the economic activities on the environment and society, depending on the economic-social and political situation (Čiulevičienè \& Kozuch, 2015). Kosonen (2009), Fullerton (2010) and others emphasize the positive effects of environmental taxes, as these taxes may be used to implement the national sustainable development goals.

In view of the importance of environmental taxes in line with the scientific literature analysis results, three key functions of environmental taxes could be identified:

- the regulatory function manifesting itself in that the tax system is used to promote or hault a certain economic activity and influence the macroeconomic processes (growth, inflation, employment) (by adusting the taxes and rates thereof); 
- the fiscal function manifesting itself in that the national budget revenues are generated essentially by virtue of the national tax system formed;

- the redistributory function manifesting itself in that the tax payers' funds accumulated on the basis of the fiscal function are redistributed among the economic entities of the country. (Miceikienè \& Čiulevičienè, 2014).

A lot of scholars associate the functions of environmental taxes with the "double dividends". Double dividends manifest themselves in the following ways: one type of the double dividends is the so-called green dividends, which emerge where the GHG emission is reduced upon introduction or correction of the environmental taxes. This is the implementation of the regulatory function. Compared to the conventional regulatory policy, which is based on technology authorizations and emission standards, these taxes may potentially reduce the expenses incurred in the efforts towards the aspired level of environmental protection (Fullerton, 2010).

The second type is the so-called blue dividends, which perform the fiscal and redistributory functions by redistribution of the revenues from the environmental taxes. The revenues are redistributed in a way so as to reduce the taxes which do not have any positive effect on environmental protection (Environmentally Related Taxes, 2001). N. Rivers (2013) has suggested that the redistributory effect of environmental taxes is very important in the climate change mitigation processes, promoting more jobs, as they would entail lower contributions into the state social security.

Having analysed the long- and short-term effects of the environmental taxes in a growing economy, Oueslati (2013) has found that reduction of a percentage share of the labour revenues while increasing the share of the environmental taxes in the GDP promotes economic growth and improvement of the general welfare of the country. This is the positive long-term effect of the tax. Nonetheless, the environmental taxes have a negative short-term effect. The negative effect comes in the form of reduction of competitiveness of the country. According to Barde (2004), when implementing the environmental tax reform, countries encounter the risk of losing their international competitiveness. Environmental taxes entail considerable costs for the countries, consequently leading to increase in the company product prices, which also affects the competitiveness.

Regardless of the negative effect, however, it should be noted that the main goal of the environmental taxes is encouragement of tax payer's positive behaviour towards environmental protection. Environmental taxes are the taxes which primarily serve the purpose of preservation of the environment (Miceikienè \& Čiulevičienė, 2014).

In general, environmental taxes could be claimed to be the most significant instrument of a national fiscal policy, capable of considerably 
reducing the pollution and/or attracting additional revenue into the national budget, which could then be redistributed in the view towards the environmental goals.

\section{Interplay Between the Environmental Taxes and Environmental Pollution in Individual Business Sectors in Lithuania}

To analyse the interplay between the environmental taxes and environmental pollution in Lithuania, it would be reasonable to identify all the environmental taxes paid and the degree of their collection in individual groups of economic activities.

The Lithuanian Department of Statistics provides the following definitions of the 4 environmental taxes and their collection statistics:

- Energy taxes - excise on the imported and produced petroleum and other petroleum products as well as deductions of the Ignalina Nuclear Power Plant from the revenues from the electricity sold;

- Transport taxes collected for the cargo vehicles registered in the Republic of Lithuania, road usage by the vehicles exceeding the maximum permissible dimensions, load, and weight. These taxes also cover the tax for traffic restriction as well as target funds for the Road Maintenance and Development programme. It should be noted that the road user charge (vignettes) is attributed to the revenues for the services in line with the Eurostat guidelines and does not comprise the transport taxes;

- Resource tax, which is paid for the mineral resources, water, and construction soil, as well as use of the resources of hunted animals. This tax does not include the taxes on state natural resources, including petroleum and gas resources as well as mandatory deductions from the revenues for the wood in the rough sold (paid by the state-owned forest tenants);

- Pollution tax, the object of which is defined by the Law of Lithuania on the Tax on Environmental Pollution, namely, the emissions from mobile and stationary sources; products which are not components of any product produced on or brought (imported) into the territory of the Republic of Lithuania, the absence of which render the latter being unsuitable for the intended use, and the filled package.

The environmental tax payer is an entity, which uses or influences the tax base - energy, transport, pollution and resources - in implementation of its activity (Environmental taxes, 2013).

In Lithuania, collection of the environmental taxes is based on the Classification of Economic Activities in the European Community (NACE), 2 rev (Table 1) (NACE, 2016). 
Table 1. Classification of Economic Activities in the European Community (source: made by the authors according to the data by Eurostat, 2019)

\begin{tabular}{|c|c|c|c|c|c|}
\hline Code & Description & Code & Description & Code & Description \\
\hline A & $\begin{array}{c}\text { Agriculture, forestry and } \\
\text { fishing }\end{array}$ & $\mathrm{H}$ & Transportation and storage & $\mathrm{O}$ & $\begin{array}{c}\text { Public administration and } \\
\text { defence; compulsory social } \\
\text { security }\end{array}$ \\
\hline B & Mining and quarrying & $\mathrm{I}$ & $\begin{array}{c}\text { Accommodation and food } \\
\text { service activities }\end{array}$ & $\mathrm{P}$ & Education \\
\hline C & Manufacturing & $\mathrm{J}$ & $\begin{array}{c}\text { Information and } \\
\text { communication }\end{array}$ & $\mathrm{Q}$ & $\begin{array}{c}\text { Human health and social } \\
\text { work activities }\end{array}$ \\
\hline $\mathrm{D}$ & $\begin{array}{c}\text { Electricity, gas, steam and } \\
\text { air conditioning supply }\end{array}$ & $\mathrm{K}$ & $\begin{array}{c}\text { Financial and insurance } \\
\text { activities }\end{array}$ & $\mathrm{R}$ & $\begin{array}{c}\text { Arts, entertainment and } \\
\text { recreation }\end{array}$ \\
\hline $\mathrm{E}$ & Water supply & $\mathrm{L}$ & Real estate activities & $\mathrm{S}$ & Other service activities \\
\hline $\mathrm{F}$ & Construction & $\mathrm{M}$ & $\begin{array}{c}\text { Professional, scientific and } \\
\text { technical activities }\end{array}$ & $\mathrm{T}$ & $\begin{array}{c}\text { Activities of households as } \\
\text { employers }\end{array}$ \\
\hline $\mathrm{G}$ & $\begin{array}{c}\text { Wholesale and retail trade, } \\
\text { repair of motor vehicles } \\
\text { and motorcycles }\end{array}$ & $\mathrm{N}$ & $\begin{array}{c}\text { Administrative and support } \\
\text { service activities }\end{array}$ & $\mathrm{U}$ & $\begin{array}{c}\text { Activities of extraterritorial } \\
\text { organisations and bodies }\end{array}$ \\
\hline
\end{tabular}

According to the statistical information provided by the Lithuanian Department of Statistics, the environmental taxes are not collected in certain groups of economic activity, or the volumes collected are insignificant. For this reason, analysis of collection of the environmental taxes in these groups would be unreasonable. The authors of the present article have identified five groups of economic activities generating significant volumes of the environmental taxes collected: A - agriculture, forestry and fishing, C manufacturing, D - electricity, gas, steam and air conditioning supply, G wholesale and retail trade, repair of motor vehicles and motorcycle and $\mathrm{H}-$ transportation and storage. The analysis of the environmental taxes in the leading groups in the period 2008-2016 allows to identify their collection weight and dynamic trends (Fig. 1).

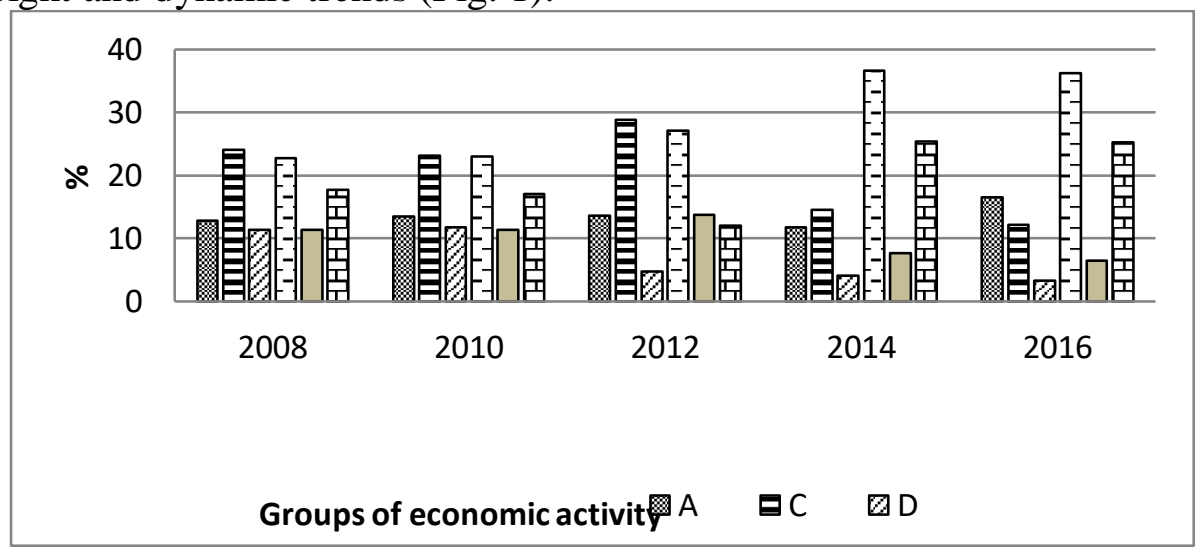

Figure 1. Collection of the environmental taxes by groups of economic activity, 2008-2016, \%

(source: made by the authors according to the data by Eurostat, 2019) 
Data in Fig. 1 suggest that the largest volume of the environmental taxes is paid by the wholesale and retail trade, repair of motor vehicles and motorcycle (group of economic activity $\mathrm{G}$ ), accounting for 22 to $36 \%$. In the period analysed, the environmental taxes collected from this activity increased by $63 \%$. Electricity, gas, steam and air conditioning supply (group of economic activity D) and land, air, water transportation (group of economic activity $\mathrm{H}$ ) accounted for about $11 \%$ in 2008 , while in 2016, the environmental taxes collected from these activities reduced significantly, respectively, to $3.3 \%$ and $6.5 \%$. The environmental taxes collected from agriculture, crop, animal production, forestry, logging, etc. (group of economic activity A) increased by $28 \%$ in the period analysed. The environmental taxes collected from manufacturing, furniture production (group of economic activity C) reduced by half. It could be claimed that the environmental tax collections had a downward trend, except for the following two groups of economic activities: wholesale and retail trade of motor vehicles and motorcycles (group of economic activities G) and agriculture (group of economic activity A).

The Lithuanian Department of Statistics provides data on twenteen pollutant groups by type. These are sulfur dioxide; nitrogen oxides; carbon monoxide; carbon dioxide from biomass, methane; hydrofluorocarbons, sulfur hexafluoride, non-methane volatile organic componds, solids, ammonnia, etc. The pollutant groups are presented in tons and by groups of economic activity. Table 2 provides the comparative analysis of the environmental taxes and emissions in percentage. The groups of economic activity analysed are the groups characterised by the highest value of emissions.

Table 2. The environmental taxes collected and emissions by groups of economic activity

(GEA), 2008-2016, \% (source: made by the authors according to the data by Eurostat, 2019)

\begin{tabular}{|l|l|l|l|l|l|l|l|l|l|l|}
\hline GEA & 2008 & \multicolumn{2}{|l|}{} & \multicolumn{2}{l|}{2010} & 2012 & 2014 & 2016 & \\
\cline { 2 - 11 } & $\begin{array}{l}\text { Env. } \\
\text { taxes }\end{array}$ & $\begin{array}{l}\text { Emissi- } \\
\text { ons }\end{array}$ & $\begin{array}{l}\text { Env. } \\
\text { taxes }\end{array}$ & $\begin{array}{l}\text { Emissi- } \\
\text { ons }\end{array}$ & $\begin{array}{l}\text { Env. } \\
\text { taxes }\end{array}$ & $\begin{array}{l}\text { Emissi- } \\
\text { ons }\end{array}$ & $\begin{array}{l}\text { Env. } \\
\text { taxes }\end{array}$ & $\begin{array}{l}\text { Emissi- } \\
\text { ons }\end{array}$ & $\begin{array}{l}\text { Env. } \\
\text { taxes }\end{array}$ & $\begin{array}{l}\text { Emissi- } \\
\text { ons }\end{array}$ \\
\hline $\mathrm{A}$ & 12.80 & 29.29 & 13.5 & 27.39 & 13.60 & 24.18 & 11.80 & 20.86 & 16.50 & 16.73 \\
\hline $\mathrm{C}$ & 24.02 & 16.22 & 23.2 & 15.50 & 28.80 & 16.78 & 14.76 & 19.04 & 12.20 & 18.88 \\
\hline $\mathrm{E}$ & 4.01 & 11.21 & 3.64 & 11.36 & 3.72 & 9.74 & 5.64 & 8.57 & 4.65 & 7.25 \\
\hline $\mathrm{G}$ & 22.78 & 9.20 & 23.00 & 12.96 & 27.10 & 16.57 & 36.6 & 19.08 & 36.20 & 33.42 \\
\hline $\mathrm{H}$ & 11.4 & 23.54 & 11.44 & 22.24 & 13.70 & 23.87 & 7.71 & 23.71 & 6.49 & 15.91 \\
\hline Other & 24.99 & 10.54 & 25.22 & 10.55 & 13.08 & 8.86 & 23.49 & 8.74 & 23.96 & 7.81 \\
\hline
\end{tabular}

The data presented in Table 2 suggest that, in 2008, agriculture, logging (group of economic activity A) and land, water, air transport activity (group of economic activity $\mathrm{H}$ ) as well as water collection and wastewater treatment (activity group E) were the largest polluters. Emissions generated 
by these three groups accounted for more 64\%. Nonetheless, in 2016, there was a considerable decrease in emissions by these three groups of economic activities, respectively, by $75 \%, 48 \%$, and $64 \%$. Emissions generated by wholesale and retail trade, repair of motor vehicles and motorcycles (group of economic activity $G$ ) increased by 3.5 in the period analysed. In 2016, emissions from all the groups of economic activity accounted for more $33 \%$. Insignificant increase of about $14 \%$ in the emissions was registered in the manufacturing, furniture production (group of economic activity $\mathrm{C}$ ).

In general, three groups of economic activity: agriculture and logging (group of economic activity A), manufacturing and furniture production (group of economic activity $\mathrm{C}$ ), wholesale and retail trade, rpair of motor vehicles and motorcycles (group of economic activity G), have stood out in analysis of the environmental taxes in relation to emissions. These groups of economic activity generate the largest volumes of the environmental taxes collected due to the largest volumes of emissions.

It is important that the analysis of environmental taxes includes assessment of their weight in the total tax revenues (Table 3).

Table 3. Indicators of environmental taxes and tax revenues in Lithuania, 2008-2016 (source: made by the authors according to the data by Eurostat, 2019)

\begin{tabular}{|l|l|l|l|l|l|}
\hline Year & $\mathbf{2 0 0 8}$ & $\mathbf{2 0 1 0}$ & $\mathbf{2 0 1 2}$ & $\mathbf{2 0 1 4}$ & $\mathbf{2 0 1 6}$ \\
\hline Environmental taxes, thous. EUR & 272422 & 254492 & 308944 & 333823 & 406476 \\
\hline Tax revenues, thous. EUR & 7021958 & 4625398 & 5520730 & 6115831 & 6912155 \\
\hline $\begin{array}{l}\text { Share of the environmental taxes in the } \\
\text { tax revenues, \% }\end{array}$ & 3.88 & 5.50 & 5.60 & 5.46 & 5.88 \\
\hline
\end{tabular}

The data presented in Table 3 suggest that the share of the environmental taxes in the total tax revenues increased and accounted for more $5 \%$ of the tax revenues in the period analysed, except for the year 2008.

Analysis of the environmental taxes by their classification by individual tax enables determination of their individual weight and trends in the analysed period 2008-2016 (Fig. 2).

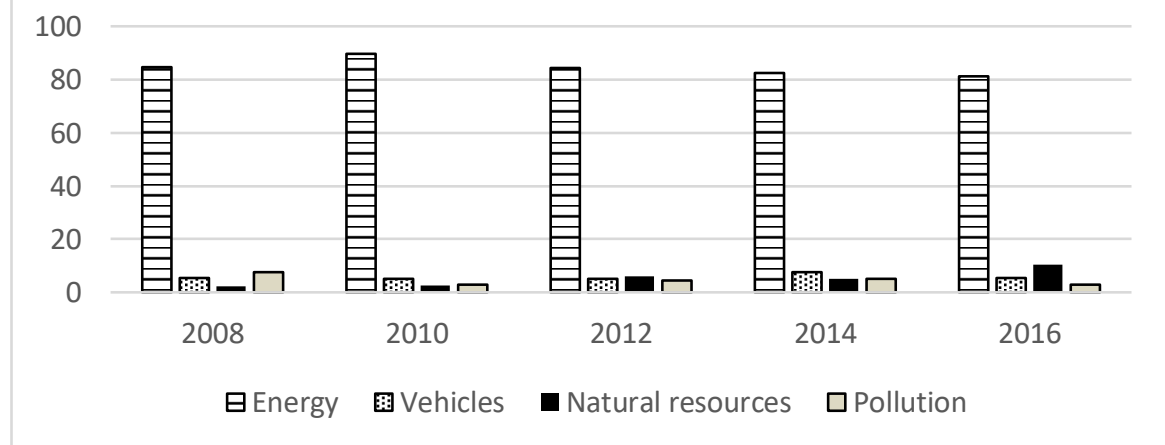

Figure 2. Dynamics of the environmental taxes in 2008-2016, \% (source: made by the authors according to the data by Eurostat, 2019) 
The data presented in Fig. 2 suggest that the energy tax accounts for the largest share in the environmental taxes collected. The annual volume of the energy tax collected accounted for about $80 \%$ of the total environmental taxes on average. The largest volume of the energy tax collected was registered in 2010, but, as of 2010, the volumes of this tax collected reduced each year.

Pollution tax collection volumes reduced each year, or by about 2.6 in total in the period analysed. Nonetheless, the natural resource extraction tax collection volumes increased by 4.3. The largest volume of the natural resource extraction tax collected was registered in 2016 and accounted for more $10 \%$, and as of 2012, the volumes of this fee collected increased each year.

The largest volume of the vehicle tax collected was registered in 2014 and accounted for about $7.4 \%$. The figure was about $5 \%$ in all the rest periods analysed. It is important that the analysis of the role of environmental taxes involves the properties which make these taxes necessary.

Table 4. Collection of the Gross Domestic Product (GDP) and environmental taxes by groups of economic activity (GEA), 2008-2016, \% (source: made by the authors according to the data by Eurostat, 2019

\begin{tabular}{|l|l|l|l|l|l|l|l|l|l|l|}
\hline \multirow{2}{*}{ GEA } & 2008 & \multicolumn{2}{|l|}{2010} & 2012 & 2014 & \multicolumn{2}{l|}{2016} \\
\cline { 2 - 12 } & GDP & $\begin{array}{l}\text { Env. } \\
\text { taxes }\end{array}$ & GDP & $\begin{array}{l}\text { Env. } \\
\text { taxes }\end{array}$ & GDP & $\begin{array}{l}\text { Env. } \\
\text { taxes }\end{array}$ & GDP & $\begin{array}{l}\text { Env. } \\
\text { taxes }\end{array}$ & GDP & $\begin{array}{l}\text { Env. } \\
\text { taxes }\end{array}$ \\
\hline $\mathrm{A}$ & 19.27 & 12.80 & 18.33 & 13.50 & 18.70 & 13.60 & 18.05 & 11.80 & 18.46 & 16.50 \\
\hline $\mathrm{C}$ & 17.12 & 24.02 & 18.34 & 23.20 & 19.81 & 28.80 & 19.18 & 4.76 & 18.34 & 12.20 \\
\hline $\mathrm{F}$ & 6.34 & 3.75 & 3.47 & 3.55 & 3.50 & 3.46 & 4.3 & 5.76 & 3.75 & 3.75 \\
\hline $\mathrm{G}$ & 20.11 & 22.78 & 20.92 & 23.00 & 21.81 & 27.10 & 21.51 & 36.6 & 20.49 & 36.20 \\
\hline $\mathrm{L}$ & 7.50 & 0.22 & 7.32 & 0.23 & 6.71 & 0.51 & 6.92 & 1.43 & 7.00 & 1.90 \\
\hline Other & 29.66 & 36.43 & 31.63 & 36.52 & 29.47 & 26.53 & 30.04 & 39.65 & 31.96 & 29.45 \\
\hline
\end{tabular}

The data presented in Table 4 suggest that the greatest contribution in the GDP was made by the agricultural activity, manufacturing, and wholesale and retail trade, repair of motor vehicles and motorcycle, accounting for 18 to $20 \%$ in the GDP. These activities generated the highest volumes of the environmental taxes collected. The contribution of agricultural activity, crop, animal production, forestry, logging, etc. (group of economic activity A) reduced by about $4 \%$ of average despite of the increase in the volumes of the environmental taxes collected. The contribution of manufacturing in the GDP increased by about $7 \%$ on average, while the volumes of the environmental taxes collected reduced by half in the period analysed. The contribution of wholesale and retail, trade, repair of motor vehicles and motorcycles in the GDP changes very insignificantly (by about 1\%), while the volumes of the environmental taxes collected from this activity increased by about $63 \%$.

During the analysis of the construction (group of economic activity $\mathrm{F}$ ) and real estate activities (group of economic activity L) groups, the downward trend in the contribution of these activities in the GDP has been observed for 
each year. Considerable reduction of about $70 \%$ in the contribution in the GDP has been observed in the construction group, while the volume of the environmental taxes collected did not change in the period analysed.

In summary, three groups of economic activity have stood out after the analysis of the environmental tax collection, GDP and emissions level: group of economic activity grupe $\mathrm{C}$ ), wholesale and retail trade, repair of motor vehicles and motorcycles (group of economic activity $\mathrm{G}$ ). These groups of economic activity generate the largest volume of environmental taxes due to the largest emission volumes and largest contribution in the GDP.

\section{Recommendations on Improvement of Environmental Taxes}

To generate the recommendations on improvement of environmental taxes in Lithuania, the analysis of the trends in environmental taxes in the selected EU countries was performed. Countries of one of the two types those which have implemented the environmental tax reform (ETR) and those which have not implemented the reform - were selected. The aim of the reforms is reduction of the tax rates for the taxes distorting the market and increase of the environment-related taxes, i.e. moving the tax burden from the labour, income taxation to environmental taxation. Consequently, the share of labour taxes in the total taxes should be decreasing compared to the share of the environmental taxes in the total taxes. The countries which have implemented the reform are Finland, Germany, Denmark, Sweden, and Norway. Hence, for further assessment of the TR effect, the share of the environmental taxes in the total tax revenues and the share of the labour taxes in the total tax revenues are considered for each of the countries.

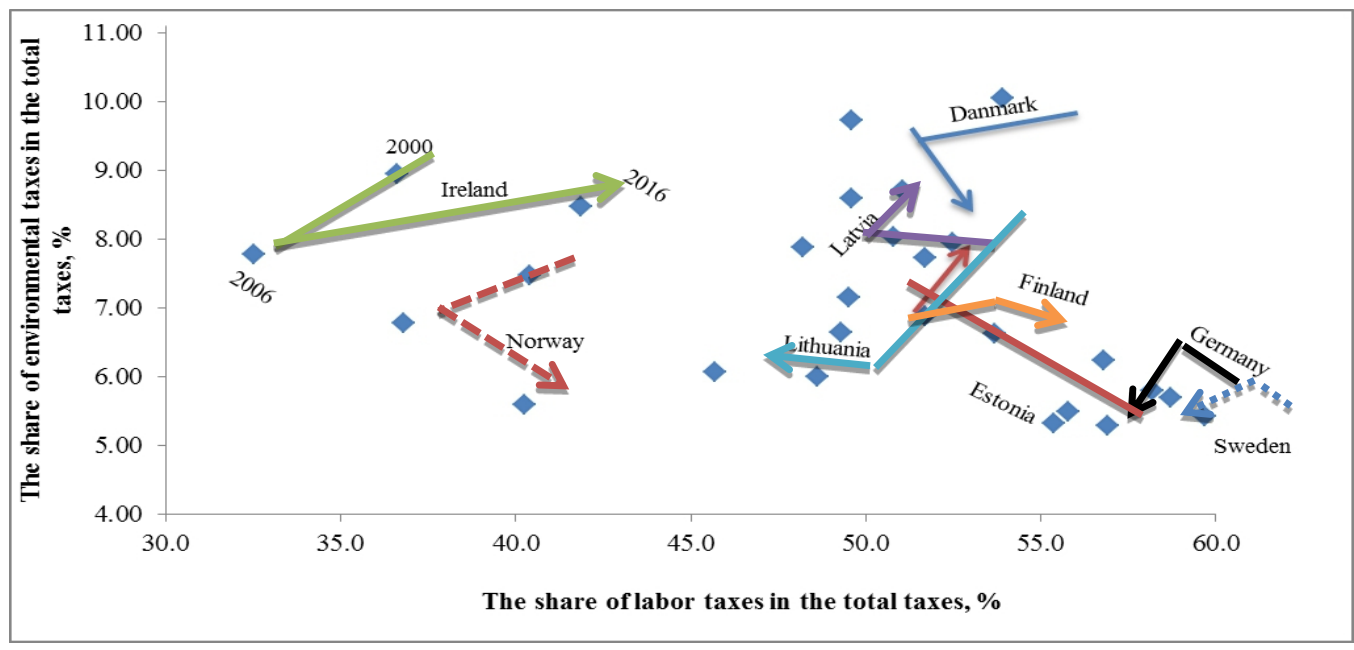

Figure 3. The effect of the environmental tax reform in 2000-2006-2016 (made by the authors according to the data by Eurostat) 
Four trends could be identified in the ETR:

- $\quad$ reduction of the weight of labour taxes in the total taxes and increase of the weight of the environmental taxes. This indicates that the country was moving towards the ETR (the upper left corner);

- $\quad$ increase of the share of the labour and environmental taxes in the total taxes. This indicates that the general level of taxes was increasing (the upper right corner);

- $\quad$ reduction of the share of the labour and environmental taxes in the total taxes. This indicates that the general level of taxes was decreasing (the bottom left corner);

- $\quad$ increase of the labour tax weight in the total taxes and reduction of the weight of the environmental taxes. This indicates that the country was moving in the anti-ETR direction (the bottom right corner).

As suggested by Fig. 3, environmental policies implemented differ from country to country, and all the countries cannot be compared to each other conclusively, as some of them (Germany, Finland, Denmark, Sweden, Norway) had already implemented the reform, while others (Ireland, Lithuania, Latvia, Estonia) were only about to be moving towards the reform. Denmark and Norway could be noticed to have reduced the share of both the environmental and labour taxes in the period 2000 to 2006; however, in the period 2006 to 2016, the share of the environmental taxes decreased even further, while the share of the labour taxes increased. Nonetheless, it would be unreasonable to claim that the countries were moving in the anti-ETR direction, as these countries had already implemented the reforms, and, as environmental pollution was reducing in these countries, the volumes of the environmental taxes collected were reducing as well. In the period 2000-2016, Germany and Sweden reduced the general level of taxes by reducing both the environmental and the labour taxes. Meanwhile, the countries which had not implemented the reform yet (Ireland, Estonia, Latvia) were showing the general increase in the level of taxes in the period 2006-2016, as the share of the environmental and labour taxes in the total taxes increased.

Hence, the analysis of the ETR effect in the European countries has suggested that Lithuania was the only country moving towards the ETR compared to the countries which had not implemented the ETR. Meanwhile, in Ireland, Latvia and Estonia, noticeable increase in the level of both the environmental and the labour taxes could be observed.

The following recommendations have been generated on the basis of the conducted statistical analysis of the dynamics of the environmental taxes and environmental pollution indicators as well as the comparative analysis of the environmental taxes in Lithuania versus other countries of the EU: 
1. The rationale behind the environmental tax rates and tax benefits should be reconsidered with the view towards reduction of the pollution by establishing the polluter-pays principle.

2. The possibilities to implement the environmental tax reform in Lithuania by using the best practice of the EU countries should be assessed.

3. The National Bioeconomy Strategy, which is in the process of development, should provide for the tax-related incentives to the activities in the bioeconomy sector which are characterised by the greatest GDP potential and low environmental pollution.

\section{Conclucions}

Environmental taxes are a very significant instrument of a national fiscal policy, which helps in the efforts towards the environmental goals and assurance of implementation of the sustainable development principles. Environmental taxes should be based on the polluter-pays principles, where full liability for environmental pollution and use of natural resources is imposed on the polluters. These taxes perform three functions: regulatory, intended to reduce the emissions; fiscal, assuring the budget revenues; and redistributory, involving redistribution of the revenues in a way so as to reduce the taxes which do not have any positive influence on environmental protection.

The groups of activity characterised by the largest environmental pollution and generating the largest volumes of taxes paid have been determined by identification of the interplay between the environmental taxes and pollution in the Lithuanian business sectors: agriculture, forestry and fishing; manufacturing; electricity, gas, steam and air conditioning supply; wholesale and retail trade, repair of motor vehicles and motorcycles; transportation and storage. The environmental taxes and pollution show the downward trend in all the groups of economic activity, except for the following two groups: wholesale and retail trade, repair of motor vehicles and motorcycle bei agriculture, forestry and fishing. The comparative analysis of the environmental tax collected, GDP and level of emissions has pinpointed the following three groups of economic activity: agriculture, forestry and fishing; manufacturing; wholesale and retail trade, repair of motor vehicles and motorcycles. These groups of economic activity generate the largest volumes of the environmental taxes, the largest volumes of emissions, and account for the greatest contribution into the GDP.

Lithuania is the only country moving towards the environmental tax reform compared to the countries which have not implemented the reform yet. The recommendation for Lithuania is to review the rationale behind the environmental tax rates and tax benefit with the view towards mitigation of the environmental pollution by establishment of the polluter-pays principles; 
to assess the possibilities for implementation of the environmental tax reform in Lithuania by building on the best practice of the EU countries. It is proposed to provide for the incentive measures in relation to the taxes for the activities in the bioeconomy sector, which are characterised the greatest GDP potential and low environmental pollution, in the National Bioeconomy Strategy, which is in the process of development.

\section{References:}

1. Albrecht, J. (2016). Green Tax Reforms for Industrial Transformation: Overcoming Institutional Inertia with Consumption Taxes. Available from: <https://onlinelibrary.wiley.com/doi/abs/10.1002/sd.286 >.

2. Bruvoll, A. (2009). On the measurement of environmental taxes. Available from: <//www.ssb.no/a/publikasjoner/pdf/DP/dp599.pdf > .

3. Čiulevičienè, V., Kożuch, A.J. (2015). Aplinkosauginių mokesčių reformų efektai. Available from: $<$ https://www.researchgate.net/publication/287971963

_Aplinkosauginiu_mokesciu_reformu_efektai>.

4. Ekins, P., Pollitt, H., Summerton, P., Chewpreecha, U. (2012). Increasing carbon and material productivity through environmental tax reform. Available from: <https http://dx.doi.org/10.1016/j.enpol>.

5. Ekins, P., Pollitt, H., Summerton, P., Chewpreecha, U. (2012). Increasing carbon and material productivity through environmental tax reform.

Available from:<https://www.sciencedirect.com/science/article/pii/S030142151 100992X?via\%3Dihub>.

6. Environmental taxes (2013). A statistical guide. Available from:<https://ec.europa.eu/eurostat/web/products-manuals-andguidelines/-/KS-GQ-13-005>.

7. Environmentally Related Taxes in OECD Countries (2001). Issues and Strategies. Available from:

<https://www.cbd.int/financial/fiscalenviron/g-fiscaltaxes-oecd.pdf $>$.

8. Fullerton, D., Leicester, A., Smith, S. (2010). Environmental taxes. Available from:

$<$ https://www.researchgate.net/publication/5189204_Environmental_ Taxes $>$.

9. Statistical classification of economic activities in the European Community (NACE) (2016). Available from: $<$ https://ec.europa.eu/eurostat/statisticsexplained/index.php/Glossary:Statistical_classification_of_economic _activities_in_the_European_Community_(NACE) $>$.

10. Kosonen, K., Nicodeme, G. (2009). The role of fiscal instruments in environmental policy. Available from: 
$<$ https://publications.europa.eu/en/publicationdetail//publication/4409 d2e3-6131-4127-98c4-273f287778ce>.

11. Meškys, L. (2006). Europos Sajungos aplinkosaugos principo „teršejas moka" igyvendinimas Lietuvos Respublikos teisès sistemoje. Available from:

https://www3.mruni.eu/ojs/jurisprudence/article/view/2899.

12. Miceikienė, A., Čiulevičienè, V. (2014). Mokesčiai - kaip aplinkos taršą mažinantis ir aplinkos išteklius tausojantis instrumentas. Available from: $<$ http://erd.asu.lt/ssaf/article/viewFile/138/121 $\rangle$.

13. Nacionalinè aplinkos apsaugos strategija. (2016). Available from:<https://am.lrv.lt/uploads/am/documents/files/Strateginis\%20pl anavimas/Ataskaitos/NAAS\%20leidinys\%20LT.pdf $>$.

14. Nacionalinè darnaus vystymosi strategija. (2003). Available from: $<$ $\mathrm{http}: / /$ am.lrv.lt/lt/veiklos-sritys-1/es-ir-tarptautinisbendradarbiavimas/darnus-vystymasis/darnus-vystymasis-irlietuva/nacionaline-darnaus-vystymosi-politika>.

15. OECD (2010). Taxation, innovation and the environment. OECD Publishing. Available from: http://www.oecd.org/env/toolsevaluation/taxationinnovationandtheen vironment.htm>.

16. Pigou Arthur C (1932): The Economics of Welfare. Available from: $<$ https://www.econlib.

org/library/NPDBooks/Pigou/pgEW.html?chapter_num=3\#bookreader>.

17. Queslati, W. (2013). Short and Long-term Effects of Environmental Tax reform. Centre forRural Economy. Newcastle University. UK. Availablefrom:<http://ageconsearch.umn.edu/bitstream/146354/2/ND L2013-009.pdf $>$.

18. Rivers, N. (2013). Renewable energy and unemployment: A general equilibrium analysis //Resource and Energy Economics. No. 35: 467485.

19. United Nations (1998). Kyoto protocol to the United Nations Framework Convention on Climate Change. Available from: <http://unfccc.int/resource/docs/convkp/kpeng.pdf>. 